\title{
ASSESSING ADMINISTRATIVE STRATEGIES FOR ENHANCING PEACE EDUCATION IN JUNIOR SECONDARY SCHOOLS IN THE AGADEZ REGION, NIGER REPUBLIC
}

\section{IDI CHEFFOU}

\begin{abstract}
This study was carried out to assess administrative strategies for enhancing Peace Education (PE) in 29 Junior Secondary Schools in the region of Agadez, Niger Republic. The study was descriptive. Quantitative and non-parametric data that helped determine majority views were collected, tallied, converted into simple percentages and means using a calculator. Information from documents that were initially in French was translated into English. The research used a total population of 487 teachers and school administrators from 29 Junior Secondary Schools in the region of Agadez. All the 84 administrators from the 29 Junior Secondary Schools were included in the research as their number was small; 388 teachers were sampled out of 403 using the Research Advisors' Sample Size Table and Simple Random Technique. The research instrument was a self-designed structured questionnaire titled Administrative Strategies for Enhancing Peace Education Questionnaire, which was validated and had a reliability index of .75. This paper dealt with the curriculum content that could enhance Peace Education in Junior Secondary Schools in the region of Agadez. The findings revealed that the Peace Education curriculum content was scanty. The study recommended, among others, that the Junior Secondary Schools Peace Education curriculum should be revised, and should therefore encompass relevant issues that would mould the students' minds, issues that would help them to learn to live together and enhance mutual understanding in community; to this end, the Peace Education curriculum should mainstream Human Rights Education, Conflict Resolution Education, Disarmament Education, Development Education, International Education, Civics and any other type of education that is likely to bar the students from getting involved in violent conflict or even terrorism.
\end{abstract}

Key words: Peace, peace education, curriculum aspect

\section{Introduction}

Niger is a country of desert, drought and very few natural resources. In the northern area two-thirds of the country with a total land mass of $1,267,000 \mathrm{~km}^{2}$ is part of the inhospitable Sahara Desert and only 3\% of the land is arable. Nomadic peoples, the Tuaregs, Tubus and Fulani herders and the Arabs had been forced to move into the south, competing for resources needed by the other communities like the Hausa (55.4\%), Zarma (21\%), Fulani (8.5\%), Arabs (0.4\%), Beriberi-Kanuri(4.7\%), Tuaregs (9.3\%), Gurmance $(0.4 \%)$ and others $(0.1 \%)$ (CIA World Factbook @ http://en.wikipedia.org/CIA_World_Factbook, retrieved June 22, 2013).

While the circumstances of survival are harsh in Niger, there has not been a culture of violence. The nomadic and sedentary peoples of Niger had a long history of coexistence until the French settlers concocted a social conflict that set some tribes against others. Also, a series of armed rebellions launched by the Tuaregs and later on by the Tubus, since the early 1960s (1962-1964/1990-1995), added to the country's social unrest (4 coups d'état from 1974 to 2010). Furthermore, the period of 1983-1993 saw the collapse of the world uranium market, and the country's economy entered into recession (Nachega $\&$ Fontaine, 2006). Moreover, much of the non-desert portions of the country, which formed the backbone for subsistence crops and livestock, were devastated by severe drought cycles between 1972 and 2000. These conditions made it difficult for the State to 
provide citizens with food, water, health services and other critical human development indices. This consequently resulted in frustration, insurgencies, armed rebellions, terrorism and other destabilizing activities. This situation was worsened and perpetuated by corruption, mismanagement, weak political processes, and insecurity beyond the capacity of Government as well as external interventions aimed at destabilization.

In order to reverse the ugly trend which has persisted over the years, peace education became one of the most viable options of entrenching a culture of peace for the present and future generations of Nigériens. Peace education is very critical in ensuring a progressive and prosperous society. It is only with peace in society that the youths, who are the leaders of tomorrow, will eschew violence, and embrace the principles of brotherhood, unity, cooperation and patriotism. Therefore, peace education is essential in ensuring rapid social, political, cultural and technological development in Niger Republic.

This paper looked into coherent and logical administrative strategies that could be devised and executed systematically, with focus on peace education curriculum content. This paper would also attempt to define some key concepts like peace and peace education.

\section{The Concept of Peace}

Deriving from the Latin pax, peace in the Western world is generally considered a contractual relationship that implies mutual recognition and agreement. Understandings of peace throughout the world often disclose a much deeper comprehension of peace in relation to the human condition, which also includes inner peace (Miller, 2005). Groff and Smoker ( 1996) depicted six (6) categories of peace that corresponded to the evolution of peace thinking in Western peace research: these categories included Peace as the absence of war, Peace as a balance of forces in the international system, Positive Peace, when there is no structural violence, Negative Peace as the mere absence of war or violent conflict, Feminist Peace as the abolition of macro level organized violence on women such as war and also the micro level organized violence on women such as rape in war or in the home; moreover there is Gaia Peace which places a very high value on the relationship of humans to bioenvironmental systems and the last being Holistic, Inner and Outer Peace which views inner, esoteric (spiritual) aspects of peace as essential.

\section{The Concept of Peace Education (PE)}

Historically, peace education has grown out of the work of educators such as Dewey, Montessori, Freire, Galtung, Boulding and Boulding (2013) and many others. Galtung and Ikeda cited in Noah and Dosunmu (2012) explain "peace studies" as evolving from a focus on research and building knowledge to an emphasis on skill-building. For Galtung and Ikeda (in Noah and Dosunmu, 2012), peace education brings together multiple traditions of pedagogy, theories of education and international initiatives for the advancement of human development through learning. It is fundamentally dynamic and interdisciplinary. In other words, many teachers infuse peace education into traditional academic subjects such as literature, maths, science, history, language, civics, and the arts.

Reardon (1998), a pioneer of the wave of peace education, has argued that the general purpose of peace education is to provide the development of an authentic planetary consciousness that will enable us to function as global citizens and to transform the 
present human condition by changing the social structures and the patterns of thought that have created it. Peace education aims not to reproduce but to transform. It consists of, like Dewey $(1916,1966)$ stressed, people consciously striving to educate their successors not for the existing state of affairs but so as to make possible a future better humanity.

Gumut cited in Gyot, Dambo and Suwa (2012) holds that peace education is the deliberate attempt to educate children and adults in the dynamics of conflict and the promotion of peacemaking skills in homes, schools, and communities throughout the world, using all the channels and instruments of socialization it provides education for global security. Moreover, Gumut in Dambo and Suwa, (2012) emphasizes the human and social dimension of peace. He posits that peace introduces the concept of human dignity and human right with specific reference to such values as economic equity, political participation, ecological balance and particularly the formative principles fundamental to international human standards. Usman (2011) stresses the role peace education plays in changing people's mindsets towards a culture of non-violence. $\mathrm{He}$ asserts that peace education tackles the culture of violence and aggressions and inculcates values of non-violent change among youth and adults. Harris (2004) has come up with five different types of peace education: international education, human rights education, development education, environmental education and conflict resolution education. These different types of peace education have a family resemblance. They have in common the attempt to explain different forms of violence and provide information about alternatives to violence. To sum up, even though peace education is a global issue, the local sociocultural specificities are to be considered in designing a peace education curriculum.

\section{The Concept of Curriculum Content}

The word 'curriculum' came from the Latin word "Currere", meaning "to run a course", and traditionally, the school curriculum has presented a relatively standardized ground (a course of subjects) covered by students in their 'race' towards the finishing - (a certificate, diploma or degree) Onwuka and Bayero cited by Jimoh (2002). Moreover, the definition of curriculum can be traced back to Dewey's (1938) view of experience and education. One point to make is the difference between the concepts of curriculum and syllabus. Very frequently, the terms curriculum and syllabus are used interchangeably, but there is a great difference to be noted.

Curriculum is a wider term and it includes syllabus (Aggarwal, 2006). Curriculum is therefore an umbrella term that assumes syllabus. The curriculum sets out the subjects to be studied, their order and sequence, and so ensures some balance between humanities and science and consistency in the study of subjects, thus facilitating inter-subject links.. In the same vein, Yunusa (2000) and Onwuka (1990) see curriculum as a course of study or training leading to a product or education. Ornstein cited by Ali Moussa (2011) defines curriculum in terms of specific subjects (mathematics, science, English, history, etc.) and grade levels. Oliva (1997) has posited that curriculum is that which is taught in schools, a set of subjects, contents, a program of studies, a set of materials, a sequence of courses, a set of performance objectives, a course of study, everything that goes on within the school, including extra-class activities, guidance, and interpersonal relationships, everything that is planned by school staff, a series of experiences undergone by learners in a school, and that which an individual learner experiences because of schooling. Wilson (1990); 2004; 2006 ;) has come up with eleven (11) types of curricula, namely the overt, explicit or written curriculum, the societal curriculum, the hidden or covert 
curriculum, the null curriculum, the Phantom curriculum, the concomitant curriculum, the rhetorical curriculum, the curriculum in-use, the received curriculum, the internal curriculum and the electronic curriculum. Choice was laid upon the overt, explicit or written curriculum in this research because the main actors in educational planning i.e. the administrators, curriculum designers and teachers are fully involved in designing this type of school curriculum. No better body is more qualified to do so.

Three (3) models of curriculum were dealt with in this research, namely the managerial model (Saylor, Alexander and Lewis, 1974) the Systems Model (McDonald, 1965) and the Humanistic Model (Weinstein and Fantini, 1970). The humanistic model seemed the best model in this research because peace education, as a sensible issue, should tap not only on global standard like Peace building and Conflict Resolution strategies, but also on local and indigenous expertise.

\section{Statement of the problem}

From the 1990s to date, the economic, political and social life of the Republic of Niger has been marked by high political tensions (4 coups d'état from 1974 to 2010) and recurrent food crises across the country. This is in spite of the efforts made by the State to end the conflicts: negotiations, signing of the peace accords (Ouagadougou, April 24, 1995; Algiers, November, 28, 1997; and N'djaména, August 21, 1998), and then management of the 2007-2009 rebellion (High Commission for the Restoration of Peace, 1995), recuperation of guns, rehabilitation of ex-combatants and execution of development programmes. Conflicts have become so common and weapons so easy to possess that people do not hesitate to make use of guns as a means of settling their disagreement. The region of Agadez environment is characterized by harsh living conditions, unemployment, and a depleted ecosystem. The victims that suffer most under these deplorable and inhospitable conditions of life are generally the youths, children and women. Unfortunately, the Junior Secondary school students are mostly the ones "pushed into" armed conflicts (CAPED, 2012), being deceived that joining a front is a way of making money without consideration of the dangers involved.

From the researcher's background experience, the current curriculum content in Junior Secondary schools seems to be grossly inadequate in terms of teaching issues on Peace Education. Human Rights Education, which is supposed to inculcate respect for the dignity of man, is not properly articulated to teach the brotherhood of humankind. There is very little on development education in the curriculum. Thus, children complete Junior Secondary school without a clear view on strategies to be followed to achieve economic, political, social and cultural development of society as a way for ensuring peace and progress in society. The curriculum seems to give very little attention to conflict resolution. There is also the concern that disarmament education, which aims at disarming the students' mindsets from a culture of violence is not properly articulated to enlighten the youths for tomorrow.

\section{Research Design}

The study used a simple descriptive survey design as it sought to describe and assess the administrative strategies for enhancing Peace Education in Junior Secondary Schools in the region of Agadez, the Republic of Niger. It involved the use of questionnaires in data 
collection and analysis and interpretation of descriptive data on issues on ground on teachers and school administrators.

\section{Population of the Study}

The population in this study (Table 1 below) comprised all of the twenty nine (29) Junior Secondary Schools in the region of Agadez, Niger Republic. The 29 schools are located within the region of Agadez, and are under management of the Regional Director of Education, Literacy Programmes and the Promotion of National Languages or DREN/A/PLN. The study concerned only the teachers and the school administrators in these schools. They were included in the study because of their knowledge and experience to be able to provide correct answers to the issues raised in the questionnaire. The teachers were made up of males and females, both experienced and inexperienced as well as those with different levels of professional qualifications. All of the school administrators were included in the study because of their small number.

\section{Sample and Sampling Techniques}

Agadez is one of the two regions that suffered the atrocities of the 1990-1995 armed rebellion in Niger Republic. This study therefore purposefully selected the region of Agadez as the area to conduct the research work. There were twenty nine (29) Junior Secondary Schools in the region of Agadez, including a population of 533 teachers and 84 school administrators. All the 84 school administrators were purposively included in the research study as their number was small. Then simple random sampling technique was used to pick the sample of teachers from each school. This is to give each teacher an equal chance of being selected. Furthermore, the sampled teachers were proportionately selected from each school, as they did have the same population. Research Advisors Sample Size Table (2006 version) with 95\% confidence and 5\% of margin of error was used to pick the sample of teachers in each school. Then, to select the sampled respondents in each school the fish bowl technique also called ballot technique (Cohen, Manion, and Morrison, 2008), was used. In all, 403 teachers were sampled from 29 Junior Secondary Schools as shown in Table 1 below. All the administrators in these 29 Junior Secondary Schools were included in the study, as their number was small.

Table 1: $\quad$ Sampled Respondents

\begin{tabular}{llcccc}
\hline S/No. & \multicolumn{1}{c}{ School Institution } & $\begin{array}{c}\text { Population } \\
\text { of Teachers }\end{array}$ & $\begin{array}{c}\text { Teachers } \\
\text { sampled }\end{array}$ & $\begin{array}{c}\text { Population of } \\
\text { School } \\
\text { Administrators }\end{array}$ & $\begin{array}{c}\text { School } \\
\text { Administrators } \\
\text { included }\end{array}$ \\
\hline 1. & CES Maï Manga Oumara & 40 & 28 & 3 & 3 \\
2. & CEG Mohamed Tourawa & 18 & 10 & 1 & 1 \\
3. & CEG Assodé & 14 & 10 & 1 & 1 \\
4. & CES Tegama & 58 & 44 & 4 & 4 \\
5. & CES Moussa Djarmakoye & 41 & 28 & 3 & 3 \\
6. & CEG Katar Katar Dabaga & 10 & 10 & 1 & 1 \\
7. & CEG Azzel & 8 & 8 & 1 & 1 \\
8. & CSP Sonni Ali Ber & 4 & 4 & 4 & 2 \\
9. & CSP Oumid Mérite & 15 & 10 & 2 & 2 \\
10. & CSP Tina & 1 & 1 & 2 & 2 \\
11. & CSP Mamar & 2 & 2 & 2 & 1 \\
12. & CES Aba Wajé & 44 & 28 & 1 & 2 \\
13. & CSP Annoura Mousnat & 8 & 8 & 2 & 5 \\
14. & CEG Ibrahim Mohamed/Arlit & 34 & 28 & 5 & 13 \\
15. & DDES Arlit (LJSSO) & - & - & 13 & \\
\hline
\end{tabular}




\begin{tabular}{|c|c|c|c|c|c|}
\hline 16. & CEG Sidi Abdoul Aziz/Arlit & 27 & 19 & 2 & 2 \\
\hline 17. & CEG III/Arlit & 16 & 10 & 2 & 2 \\
\hline 18. & CEG Azourou/Akokan & 21 & 19 & 4 & 4 \\
\hline 19. & CES Aghoumboulou/Timia & 7 & 7 & 1 & 1 \\
\hline 20. & CES Sanda Maigari/Arlit & 26 & 19 & 4 & 4 \\
\hline 21. & CES Bachir Baderi/Akokan & 38 & 28 & 6 & 6 \\
\hline 22. & CES Tamgak/Iférouane & 16 & 10 & 4 & 4 \\
\hline 23. & DDES/Bilma Junior Sec. Schools & 30 & 28 & 5 & 5 \\
\hline 24. & CEB/CB/Tabelot & 5 & 5 & 2 & 2 \\
\hline 25 . & CES/AS/Tchirozérine & 27 & 19 & 2 & 2 \\
\hline 26 & CES/EBD/Ingall & 8 & 8 & 1 & 1 \\
\hline 27. & CES/TB/Adebissanat & 13 & 10 & 2 & 2 \\
\hline \multirow[t]{2}{*}{28.} & CSP/La Grace/Tchirozérine & 2 & 2 & 4 & 4 \\
\hline & Total & 533 & 403 & 84 & 84 \\
\hline
\end{tabular}

\section{Instrumentation}

A self-designed structured questionnaire titled Administrative Strategies for Enhancing Peace Education Questionnaire (ASEPEQ) was used as the instrument of data collection. A questionnaire is "a widely used and useful instrument for collecting survey information, providing structured, often numerical data, being able to be administered without the presence of the researcher, and often being comparatively straightforward to analyze" Wilson and McLean in Cohen, Manion and Morrison (2008). The questionnaire was based on a two-point scale of "Yes" or "No". The essence was to get percentage agreement or disagreement that could be used to determine majority view. The instrument was made up of eight (8) sections. Each section had a set of questions that attempted to provide viewpoints on each of the variables under investigation. This paper concentrated only on the first section, i.e. curriculum content.

\section{Validity of Instruments}

The self-designed structured questionnaire was submitted to the research supervisors and other experts in the Faculty of Education and Extension Services, Usmanu Danfodiyo University, Sokoto. Initially, each section was separated and typed on a separate page, but all the sections were later brought together as a continuous questionnaire. The research supervisors and other experts' observations and corrections were effected in the original questionnaire to upgrade its standard and accuracy. The first section of the questionnaire that related to curriculum content had 6 items which included reviewing the PE content, human rights education, development education, conflict resolution education, disarmament education and international education. Some items were modified and restructured for clarity. The instrument was judged to possess content validity.

\section{Reliability of Instruments}

The test - re-test method was used to determine the reliability of the instrument. A pilot study was conducted in two schools in Tahoua city. Tahoua is in the same geographical area as Agadez, and had been hit by the 1990s armed rebellions, too. The schools were not part of the ones used in the study. The instrument was administered to the pilot schools and scored at the same time and day. After an interval of three weeks, the instrument was re-administered and re-scored at the same time and day. The results of the two sets of scores were correlated using Pearson's Product Moment Correlation 
Coefficient. A correlation coefficient $r=0.75$ was obtained, which indicated that the instrument was reliable enough to be used for the conduct of the study.

\section{Method of Data Collection}

It is worth stressing the language policy in Niger Republic. Even though Niger Republic is a francophone country, the English language is also a compulsory subject from grade 7 to tertiary education. So many civil servants who successfully completed higher education can read documents in either French or English. Given that a good number of teachers could read the questionnaires in either language stated above, the researcher had translated the questionnaire for data collection into French. In addition, the original Peace Education curriculum for Junior Secondary Schools which was in French was translated into English Moreover, some references provided in this study were in French, and so were some documents that the researcher came across. Table 2 below showed the rate of returns of the questionnaire.

Table 2: Rate of return of questionnaires

\begin{tabular}{lcccccc}
\hline \multicolumn{2}{l}{$\begin{array}{l}\text { Categories of Questionnaires } \\
\text { respondents }\end{array}$} & $\begin{array}{c}\text { Questionnaires } \\
\text { distributed }\end{array}$ & returned & Percentage & \multicolumn{2}{c}{ quest. Not \% of quest. } \\
quest .returned (\%) returned & not returned \\
\hline Teachers & 403 & 388 & $96.27 \%$ & 15 & $3.73 \%$ \\
Administrators & 84 & 84 & $100 \%$ & - & - \\
\hline \multicolumn{2}{l}{ Total } & 487 & 472 & $96.91 \%$ & - & - \\
\hline
\end{tabular}

\section{Method of Data Analysis}

Two types of data were collected: on the one hand, quantitative and non- parametric data, and then qualitative data. The quantitative data collected were then tallied, and frequencies were converted in simple percentages and means presented in tables, using a simple calculator. Majority was used to determine viewpoints of respondents. Data analyzed enabled the researcher to draw inferences that led to the findings and conclusions arrived at this study. On the other hand, qualitative data were also collected, as the researcher had read a document whose reference was provided under CAPED. The researcher had to read the document, pick the information needed, then translated it into English and interpreted it.

\section{Data Presentation}

The data relating to the curriculum content that could enhance Peace Education was presented in Table 3 below: 
Table 3: $\quad$ Aspects of instructional Curriculum content that could enhance Peace Education in Junior Secondary schools in the region of Agadez

\begin{tabular}{|c|c|c|c|c|c|}
\hline \multirow[t]{2}{*}{ S/No. } & \multirow[t]{2}{*}{ Item Statement } & \multicolumn{2}{|c|}{ Yes } & \multicolumn{2}{|c|}{ No } \\
\hline & & $f$ & $\%$ & $f$ & $\%$ \\
\hline 1. & $\begin{array}{l}\text { The curriculum content of Junior Secondary } \\
\text { Schools had included and enhanced Peace } \\
\text { Education in the region of Agadez }\end{array}$ & 137 & 29.02 & 335 & 70.98 \\
\hline 2. & $\begin{array}{l}\text { Human Rights education has been included } \\
\text { in planning the curriculum of Peace } \\
\text { Education in Junior Secondary Schools in } \\
\text { the region of Agadez }\end{array}$ & 355 & 75.21 & 117 & 24.79 \\
\hline 3. & $\begin{array}{l}\text { Development Education has been included } \\
\text { in planning the curriculum of Peace } \\
\text { Education in Junior Secondary Schools in } \\
\text { the region of Agadez }\end{array}$ & 196 & 41.53 & 276 & 58.47 \\
\hline 4. & $\begin{array}{l}\text { Conflict Resolution has been included in } \\
\text { planning the curriculum of Peace Education } \\
\text { in Junior Secondary Schools in the region of } \\
\text { Agadez }\end{array}$ & 443 & 93.85 & 29 & 06.15 \\
\hline 5. & $\begin{array}{l}\text { Disarmament Education has been included } \\
\text { in planning the curriculum of Peace } \\
\text { Education in Junior Secondary schools in } \\
\text { the region of Agadez }\end{array}$ & 442 & 93.65 & 30 & 06.35 \\
\hline 6. & $\begin{array}{l}\text { International Education has been included } \\
\text { in planning the curriculum of Peace } \\
\text { Education in Junior Secondary Schools in } \\
\text { the region of Agadez }\end{array}$ & 48 & 10.17 & 424 & 89.83 \\
\hline & Total & 1621 & 343.43 & 1211 & 256.57 \\
\hline & Mean & 270.16 & 57.23 & 201.83 & 42.77 \\
\hline
\end{tabular}

Item 1 in Table 3 above indicates that majority of the participants $(70.98 \%)$ disagreed that the curriculum of Junior Secondary Schools had included and enhanced peace education in its content in Junior Secondary Schools in the region of Agadez. Item 2 in Table 3 showed that majority of participants $(75.21 \%)$ agreed that human rights education had been included in planning the curriculum of peace education in Junior Secondary Schools in the region of Agadez. Item 3 in Table 3 indicates that majority of participants $(58.47 \%)$ disagreed that development education had been included in planning the curriculum of peace education in Junior Secondary Schools in the region of Agadez. Item 4 in Table 3 shows that majority of participants $(93.85 \%)$ agreed that conflict resolution had been included in planning the curriculum of peace education in Junior Secondary Schools in the region of Agadez. Item 5 in Table 3 indicated that majority of participants $(93.65 \%)$ agreed that disarmament education had been included in planning the curriculum of peace education in Junior Secondary Schools in the region of Agadez. Item 6 in Table 3 shows that the majority of the participants $(89.83 \%)$ disagreed that international education had been included in planning the curriculum of peace education in Junior Secondary Schools in the region of Agadez. 


\section{Summary of Findings}

Based on the analysis of the data presented in the study, the following findings were made:

Human right education, conflict resolution and disarmament education were among the aspects of curriculum content of Peace Education in Junior Secondary Schools in the region of Agadez (Table 3), as these rubrics had been included in the Junior Secondary Schools curriculum, but they were scanty. In addition, development education and international education had not been added into the curriculum.

\section{Discussion of the Major Findings}

Table 3 (The aspects of curriculum content that could enhance peace education in Junior Secondary Schools in the region of Agadez) showed that majority (70.98\%) of respondents did not agree that certain aspects of curriculum content had been included and enhanced in the peace education curriculum. The positive views expressed related to peace education, human rights education, conflict resolution education and disarmament education. Nevertheless, it should be noted that the respondents said that development education and international education were not included in the peace education curriculum content in Junior Secondary Schools in the region of Agadez, Republic of Niger.

The findings in Table 3 revealed what the teachers and administrators knew about the current peace education curriculum that was piloted from 2003 to 2005 in Niger. Following the pilot stage, teachers and administrators in the regions of Agadez and Diffa got some in-service training on peace education. In fact, the respondents truthfully spoke their minds, as peace education, human rights education, conflict resolution education and disarmament education had been included in the peace education training manual for Junior Secondary Schools. As regards the negative views expressed by the respondents (Mean: 42.77\%), the views revealed that international education and development education were not included in the Junior Secondary School training manual. Nevertheless, these missing items, i.e. development education and international education are key aspects to enhancing peace education in Junior Secondary Schools in the region of Agadez, as evidenced by this research work. In fact, development education, as stated by Leinbach (2013), Kilpatric (1985), Bako (2012) aims at raising people's living levels, creating conditions conducive to the growth of people's self-esteem through the establishment of social, political and economic systems and institutions which promote human dignity and respect. Concisely, development education aims at moral, physical and social development and peace. International education, which the respondents did not agree with, was yet to be emphasized to enhance education in Junior Secondary Schools in the region of Agadez. In fact, this research work had enabled to highlight the importance of international education, also termed as education for world citizenship whose essence was, right from the seventies (Comenius, 1969) to the twenties, Heater (1994), Scanlon (1959), to promote an understanding of others and shared values that would overcome hostilities that lead to conflict and to promote through education in schools, the interests of international justice and fraternity. 


\section{Summary of the Major Findings}

The results of the data analysis for this study revealed that:

As regards the aspects of instruction curriculum that could enhance peace education, majority views of respondents agreed that human rights education, conflict resolution, and disarmament education had been included in the Junior Secondary schools curriculum in the region of Agadez. On the contrary, respondents said that development education, along with international education had not been included in the peace education curriculum of Junior Secondary schools. The researcher, having personally taken part in the training of teachers on peace education in the regions of Agadez and Diffa agreed with the respondents' views. Nevertheless, it should be stated that research informed the researcher that even though the respondents agreed that the above mentioned rubrics had been mainstreamed in the peace education curriculum in Junior Secondary Schools in the region of Agadez, these rubrics appeared scanty and therefore need improving for the sake of a comprehensive and effective peace education curriculum.

\section{Conclusion}

Based on the major findings in this research as well as the analyses and discussions and interpretations of data, it could be concluded that, with a view to enhancing peace education in Junior Secondary Schools in the region of Agadez, the peace education curriculum, which turned out to be scanty, should be improved.

\section{Recommendations}

Based on the findings of this study and the subsequent conclusion that derived from this study, the following recommendations were proffered in order to enhance peace education in Junior Secondary Schools in the region of Agadez:

With regard to the aspects of curriculum that could enhance peace education in Junior Secondary Schools in the region of Agadez: the content of the current peace education curriculum should be revised. To this end, apart from improving on its actual content, development education and international education should be mainstreamed.

\section{References}

Aggarwal, J. C. (2006). Principles, Methods \& Techniques of Teaching, Vikas Publishing Houses, PVT LTD, India

Ali Moussa, I. (2011). Evaluation of the textbook English Africa used in the first two years of Senior Secondary School in three schools in Niamey Metropolis, PhD Thesis, UDUS, Sokoto

Bako, R.B. (2012). Education, Peace \& Development, Lead Paper presented at the $30^{\text {th }}$ Annual National Conference of the Philosophy of Education Association of Nigeria $(P E A N)$, at Usmanu Danfodiyo University, Sokoto, November $11^{\text {th }}-16^{\text {th }}, 2012$ : Theme: Peace Education \& Development 
CAPED (Cellule d'Analyse et de Prospective En Développement, The Office of the Prime Minister, 2012). Forum International sur la Paix, la Sécurité et le Développement dans l'Espace Sahélo-Saharien du Niger, Arlit, January, 22-24, 2012

CIA World Factbook @ http://en.wikipedia.org/CIA_World_Factbook, retrieved June 22, 2013.

Cohen, L., Manion, L. and Morrison, K. (2008). Research Methods in Education, $6^{\text {th }}$ Ed., Routledge

Dewey, J. (1938). Experience and Education, New York: Macmillan, New York

Dewey, John (1916, 1966). Democracy and Education, the Free Press, Macmillan Publishing

Dewey, J. ; Montessori, M., et al (2013). @ www.un.org/cyberschoolbus/peace/content/htm, retrieved June 27, 2013)

Groff, L. and Smoker, P. (1996). Creating Global Local Cultures of Peace. Peace and conflict studies, Journal, 3 (June).

Gyot, B.D. and Suwa (2012). Peace Education and National Development: The Nigerian Experience, a paper presented at the $30^{\text {th }}$ National Conference of Philosophy of Education Association of Nigeria (PEAN), held at Usmanu Danfodiyo University, Sokoto 11-16, November.

Harris, I. M. (2004). Peace Education Theory, In Journal of Peace Education, 1 (1): March.

Heater, D. (1994). Peace Through Education (London, Falmer Press).

High Commission for the Restoration of Peace (1995). State of the Peace Process

Jimoh, A. O. (2002). An Assessment of the Productive work /activity in the curriculum of Junior Secondary Schools in Zamfara State, PhD Sociology of Education.

Kilpatric, S.I. (1985). Oxford Advanced Learners Dictionary, Sunshine Home P. 238.

Leinbach, T. (nd). The Concept of Development, @ www.uky.edu/.../GEO260/Powerpoint/Concept of Development .pp. retrieved 4/11/ 2013.

McDonald, J.B. (1965). Theories of Instruction, Washington D.C. Association for Supervision and Curriculum Development.

Miller, C. (2005). A Glossary of Terms and Concepts in Peace and Conflict Studies, University for Peace, $2^{\text {nd }}$ Edition. 
Nachega, J.C. and Fontaine, T. (2006). Economic Growth and Total Factor Productivity in Niger, International Monetary Fund Niger Economy @ www.hhtp://en.wikipedia.org/wiki/Niger\#MW-head retrieved January 5, 2013.

Noah, O.A. \& Dosunmu, S.A. (2012). Peace Education: A Prognosis for Social Reconstruction in Nigeria IN Journal of Education Philosophy, 23 (2): June.

Oliva, P. (1997). The curriculum: Theoretical dimensions. New York: Longman.

Onwuka, U. (1990). Curriculum Development for Africa - Africana - Fep Publishers Ltd

Reardon, B. (1998). Comprehensive Peace Education, New York: Teachers College Press.

Saylor, J.G. and Alexander, W.M. (1974). Planning Curriculum for Schools, New York, Holt Rinehart and Wilson.

Scanlon, D. (1959). The Pioneers of International Education: 1817-1914, Teacher's College Records, 60 (4), 209-219 Stadtschlaining/Burg, Austria.

The Research Advisors (2006) Sample Size Table.

Usman, Y.H. (2011). Education for Consciousness raising and enhancing good neighbourhooliness among unfriendly cultures for sustainable livelihood and democracy in Nigeria. Proceedings of the 2011 NNCAE Conference, 18-24.

Weinstein, G. and Fantini, M. D. (1970). Towards Humanistic Education, New York: Praeger.

Wilson, L. O. (1990, 2004, 2006). Curriculum Course Packets ED 721 \& 726, unpublished.

Yunusa, M.B. (2000). Issues on Curriculum, A.B.U. Press, Zaria. 